\title{
INTERVENÇÕES URBANAS E ERRADICAÇÃO DE FAVELAS NA ÚLTIMA DITADURA MILITAR ARGENTINA (1976-1983) \\ BAJO BELGRANO E COLEGIALES
}

\section{URBAN INTERVANTIONS AND SLUM ERADICATION DURING THE LAST ARGENTINIAN MILITARY DICTATORSHIP (1976-1983) BAJO BELGRANO AND COLEGIALES}

v. 9, n. 1 [15]

jan/abr (2017)

Dossiê "Villas Miseria, Favelas y Asentamientos: nuevas rutas en Historia Urbana"
Jimena Alejandra Vega; Maria Cristina da Silva Schicchi Pontifícia Universidade Católica de Campinas jimena_vega@hotmail.com; crisschicchi@gmail.com

\section{Resumo}

Esse artigo apresenta o resultado de estudo das estratégias e práticas urbanísticas em Buenos Aires durante o último período ditatorial argentino, com o fim de entender que fatores determinaram a adoção de políticas urbanas, seus desdobramentos e as transformações estruturais resultantes que até hoje marcam o tecido urbano da cidade. O objetivo é discutir o alcance de tais intervenções, cuja prioridade consistiu na erradicação quase total das chamadas "villas miséria" ou favelas, localizadas no tecido consolidado da cidade capital com o intuito de consolidar uma imagem de cidade moderna. Buscou-se ainda identificar as características particulares de cada caso, assim como reconhecer os diversos matizes resultantes da aplicação de uma estratégia política, identificada na literatura como "ciudad blanca".

\section{Palavras-chave}

Políticas urbanas. Buenos Aires. Ditadura militar. Erradicação de favelas.

\begin{abstract}
This work presents the results of a study about the urban planning and policies adopted in Buenos Aires during the last Argentine dictatorship period with the objective of understanding which were the factors that justified these actions. Within these urban policies undertaken in this period, this article will review the ramifications of the Eradication Plan for the slums in the
\end{abstract}


city, analyzing case studies, which represent two of the firsts slums eradicated in its entirety. The purpose was to identify the particular characteristics of each case study, in order to recognize the different nuances of the political strategy implemented, identified in the literature as "ciudad blanca". Presented in this paper, the effects of these interventions and the developments that produced territorial scars on urban and social tissue, induced by new regulations when addressing the issue of slums.

\section{Keywords}

Urban planning. Buenos Aires. Military dictatorship. Slum eradication.

\section{Introdução}

O último governo militar foi um período da história Argentina que sempre suscitou reações conflitantes, um momento histórico que apresenta algumas particularidades, cujos desdobramentos sociais, políticos e econômicos são ainda hoje, mais de quarenta anos depois, objeto de estudos e avaliações. Especialmente do ponto de vista urbano, as intervenções realizadas pelo governo no autodenominado Proceso de Reorganización Nacional deixaram marcas ou cicatrizes visíveis na atualidade, cuja análise contribuirá ao entendimento das dinâmicas e interesses implícitos nestas políticas.

Neste artigo, parte-se da premissa de que dentro do contexto econômico e político da época, as intervenções urbanas conjugadas aos ideários que orientavam as políticas, que já vinham sendo estabelecidas anteriormente ao período estudado, deram lugar a uma reorganização espacial urbana que, por sua vez, resultou na configuração ou ampliação de espaços socialmente segregados, uma vez que o governo da época fazia parte e atendia exclusivamente aos interesses de uma elite urbana emergente. Além disso, para a efetivação de seus projetos, o governo contava com mecanismos somente aplicáveis numa conjuntura política ditatorial, ou seja, sem diálogo com outros agentes envolvidos no processo de construção da cidade. Considera-se que todos os fatores, tanto internos como externos, significaram uma forma paradoxal de atuar na cidade face aos desafios apresentados na época, onde ainda se pode identificar a influência das formas de pensar e de operar que vinham se colocando com anterioridade, porém desenvolvidas dentro de um contexto particular no campo político

Do ponto de vista político, procurou-se relacionar as questões de forma a reconstruir os antecedentes que influíram na elaboração das políticas municipais, com o objetivo de identificar continuidades e rupturas decorrentes da defasagem entre os diferentes tempos da ação política e das decisões técnicas. Ou seja, estabelecer o vínculo necessário entre a política relacionada a uma determinada conjuntura e a técnica, regida por princípios paradigmáticos - pragmáticos ou teóricos - que lhe permitiram transcender várias gestões. 
Dito de outra forma, o trabalho pretende contribuir para uma maior compreensão das ações do Estado no campo das políticas urbanas, buscando entender até que ponto as estratégias de intervenção adotadas contribuíram para as transformações no tecido urbano da cidade, bem como para a ampliação da fragmentação do tecido sociopolítico-espacial ${ }^{1}$ na atualidade. Podese afirmar que algumas das políticas habitacionais do último período militar surgem, por um lado, como ações de requalificação urbana influenciadas pelo ideal de modernização aspirado para a cidade, e por outro, como um instrumento de controle político e social de um governo ditatorial. Ambos os fatores, porém, estão submetidos à dinâmica da cidade capitalista e, portanto, esse aspecto será analisado com o intuito de identificar como as intervenções urbanas realizadas pelo regime da época reproduziram a lógica imposta por esta, uma vez que favoreceram a comercialização e apropriação diferenciada da terra, gerando novos processos de segregação sócio-espacial. Nesse sentido, as contradições e os conflitos inerentes ao processo de gentrificação e de segregação sócio-espacial ${ }^{2}$ serão abordados de forma a articular os conteúdos teórico-conceituais presentes na literatura, com as especificidades do espaço físico de Buenos Aires, face aos desafios apresentados para o desenvolvimento urbano local.

Procurou-se refletir sobre os efeitos das intervenções sobre a configuração espacial da cidade, examinando as políticas urbanas e as ideias nas quais se baseou o governo militar ao tratar da reorganização do espaço urbano portenho, e, ao mesmo tempo, como estas ideias se materializaram na prática, a partir da análise dos principais projetos de intervenção urbana na esfera social e territorial. Buscou-se ainda identificar as características particulares de cada caso de estudo, com o intuito de reconhecer os diversos matizes resultantes da aplicação de uma política de "ciudad blanca".

Finalmente, são analisadas as consequências destas intervenções e os desdobramentos territoriais que produziram cicatrizes no tecido urbano e social, induzidos pelas novas normativas e a abordagem da questão das favelas.

A pesquisa consistiu do levantamento bibliográfico, documental e de imagens aéreas da época, onde os dados qualitativos extraídos, e reelaborados a partir de outras fontes, permitiram dar consistência às determinantes históricas delineadas. Como resultados, foram construídos mapas a partir da análise dos Planos e Códigos de Planeamiento Urbano (CPU) de vários momentos, com o objetivo de cruzar os diferentes dados obtidos, com os aspectos teóricos levantados sobre o período.

\footnotetext{
${ }^{1}$ Adota-se aqui o conceito de Souza (2000, pág. 179) de que: "Por fragmentação do tecido sociopolíticoespacial, deve-se entender algo mais que a fragmentação usual. O termo 'fragmentação' popularizou-se, desempenhando o papel de pendant do processo de globalização, com isso indicando-se que por trás de processos de relativa homogeneização cultural e de costuramento econômico e 'compreensão espaçotemporal', têm lugar também exclusão e segmentação social"

2 Entendida como: "expressão espacial das classes sociais" o que seria a resultante do "diferencial de capacidade que cada grupo tem de pagar pela residência que ocupa" (Corrêa, 2000:62).
} 


\section{A "ciudad blanca"}

\section{ESTOY ORGULLOSO!}

Dios nos ilumine para que estas conductas, estos gestos, estas emociones, este afán de perfección, este profesionalismo, esta demostración de país moderno y ejemplar, arraiguen definitivamente entre nosotros y sirvan como norma habitual entre los argentinos. Que cuando se vayan nuestros visitantes, quede junto a cada uno de nosotros, la sensación de que nos siguen observando y que sólo con nuestra conducta ganaremos el respeto que merecemos, desde afuera. $Y$ desde adentro (Solicitada. Clarín, $1^{\circ}$ de junho de 1978, apud BLAUSTEIN, E. \& ZUBIETA, 1998, p.250) ${ }^{3}$.

Do ponto de vista do pensamento urbanístico, o período estudado representou, em alguns aspectos, uma ruptura da abordagem da questão urbana praticada nas décadas anteriores, pois foi um momento de transição entre um contexto em que havia uma primazia do Estado em relação ao Planejamento Regional, característico dos anos 1950 e 1960, e o lugar que assumiriam as operações urbanas realizadas sobre setores específicos da cidade, marcado por um contexto neoliberal e de globalização a partir dos anos 1980.

O modelo de planejamento urbano e regional, baseado em diagnósticos e estudos de tendências, entra em crise a partir da década de 1960, em sintonia com o início de um ciclo de profunda instabilidade política (alternância de regimes civis e militares). Segundo Novick (2011), o fim do crescimento econômico determinado pela crise do sistema produtivo e suas transformações, a teoria da dependência dos países periféricos na estrutura capitalista da economia mundial e as mobilizações políticas, puseram em crise o planejamento dos anos de pós-guerra. Durante os governos que sucederam a década peronista (1945-1955), se formularam vários planos de reordenamento metropolitano, os quais, entretanto, não conseguiram conciliar os interesses antagônicos dos diversos organismos jurisdicionais. Porém, a forma resultante das transformações da região metropolitana não correspondeu a nenhuma diretriz proposta nestes planos de urbanismo, produzidos por organismos do Estado (TORRES, 1993).

Em termos da dinâmica da economia mundial na época, deve-se ter em conta a disponibilidade de grande quantidade de dinheiro nos cofres do 'governo de fato' - produto de um enorme endividamento junto a organismos internacionais (em especial ao FMI, financiado pelos petrodólares dos países da OPEP, a partir dos superávits na balança comercial dos países exportadores de petróleo, gerados por estratégia decorrente da crise de 1973). Este fator permitiu ao governo argentino da época empreender planos de grande escala e viabilizar projetos de altos custos no nível nacional e municipal. Esses processos devem ser também entendidos e analisados dentro de uma visão regional latino-americana, caracterizada por um

\footnotetext{
${ }^{3}$ Faz parte do levantamento das publicações nos meios de comunicação durante o período da Copa do Mundo de 1978 , realizado por Eduardo Blaustein e Martín Zubieta, e publicado no livro intitulado "Decíamos ayer: la prensa argentina bajo el Proceso" (BLAUSTEIN, E. \& ZUBIETA, 1998).
} 
período de reconfigurações e reestruturações político-econômicas, marcado pela pósindustrialização e a abertura das economias locais ao mercado internacional, que também contribuiriam para essas transformações urbanas.

A Ciudad Autónoma de Buenos Aires, sede dos órgãos públicos nacionais e dos principais equipamentos públicos e privados, sempre representou o setor mais consolidado e de maior antiguidade da Região Metropolitana de Buenos Aires (RMBA). Para contextualizar a cidade dentro do recorte temporal deste estudo, se destaca que, a partir dos dados censitários de 1980, a RMBA contava com mais de dez milhões de habitantes, em uma superfície equivalente o 1,5\% da Província de Buenos Aires, o que, segundo análise de Oszlak (1991), significou uma concentração de aproximadamente $37 \%$ da população argentina em apenas o $0,2 \%$ da área continental. Porém, a densidade decrescia do centro para a periferia, demonstrando que toda a estrutura urbana tinha crescido historicamente em função da Capital.

No final da década de 1970 e sob o controle do último governo militar, iniciou-se um período de projetos setoriais para regular o direito à cidade, os quais modificaram não só a conformação física, mas também a social, da Capital Federal. O aumento dos investimentos que remodelaram o espaço urbano portenho envolveu diferentes agentes participantes do processo de produção da cidade, em especial, os incorporadores imobiliários, bastante favorecidos pelas ações diretas e indiretas do Estado. Produziu-se uma reestruturação do modelo políticoeconômico da Argentina do último governo militar, em que a cidade de Buenos Aires entrou em uma fase de transição para se converter em um espaço de atuação ideal para a lógica do desenvolvimento da especulação e dos negócios no ramo imobiliário. É importante destacar que a criação de espaços socialmente segregados por parte das intervenções do Estado autoritário da época foi um fator favorável aos processos de reprodução da dinâmica capitalista na cidade de Buenos Aires.

Para levar adiante essa reestruturação do país, o governo de fato teve que desenhar novas diretrizes políticas para amenizar as consequências destas mudanças. A esse respeito, Liernur (2008) afirma que o Estado, pela última vez na história argentina, teve um papel importante como impulsionador de grandes obras no país, levando em consideração que o setor da construção civil era o único que não seria ameaçado pela abertura comercial e, ao mesmo tempo, capaz de controlar os efeitos negativos sobre as fontes de emprego, produto da desativação industrial.

Portanto, o recorte temporal estudado nesta pesquisa é considerado um período de transição na história político-econômica argentina. Por um lado, significou o fim (de vários setores) da indústria nacional como motor do desenvolvimento econômico e social, com um Estado de bem-estar como principal agente de promoção social e organizador da economia, característico do modelo anterior de substituição de importações; e por outro, marcou o começo de uma política neoliberal e a consequente abertura do mercado a capitais estrangeiros, entendendo a liberação do mercado como fórmula eficaz e autosuficiente para a regulação 
econômica e financeira do país, promotora de uma modernidade universal no que diz respeito ao desenvolvimento da cidade.

Para entender o processo que a cidade de Buenos Aires atravessou nesse período é necessário ter em conta ainda outros fatores como, por exemplo, a importância da ideologia no discurso oficial dos representantes do governo, concretizada nas obras que materializariam e impactariam na imagem urbana de Buenos Aires. No caso do governo portenho, ela foi fundamental para conseguir o apoio dos grupos sociais oligárquicos para a transformação do espaço urbano, no sentido de concretizar uma imagem de cidade moderna e civilizada, 'limpa' e homogênea, transformando o interesse particular de alguns em interesse comum de todos, construindo "las condiciones para que los golpes de estado contaran con justificativos en la sociedad civil" (GAZZOLI, 2007, p.21).

Tal imagem aparece como um elemento constante ao longo do tempo, presente no discurso oficial das entidades municipais, desde as reformas efetuadas no começo do século que contemplavam uma modernização própria de cidade-capital. De caráter transversal e imutável, representação visual da cidade-vitrine, é definida por Lacarrieu (2007) como o "núcleo duro" de uma Buenos Aires sempre moderna.

Como aponta a autora, essa imagem homogeneizante se conjuga com os diferentes processos de produção de imaginários sociais, por sua vez atravessados por relações de poder que os legitimam, o que aprofunda as desigualdades e os processos de segregação sócio-espacial e cultural. Nesse período, ela é a própria projeção dos ideários urbanos das classes dominantes, utilizada como instrumento de consenso para obter a aceitação geral da sociedade e justificar as decisões tomadas sobre a cidade:

Las imágenes urbanas acaban constituyéndose en la materia prima de los discursos, los valores y las prácticas sociales. Hay imágenes que son legitimadas y se tornan hegemónicas en las disputas sociales. Suelen aspirar a definir proyectos urbanos que pretenden imponerse a la ciudadanía, conformando y trasmitiendo valores y comportamientos desde los cuales se decide qué formas de apropiación de los espacios se autorizan y qué rasgos culturales deben asumirse (LACARRIEU, 2007, p.51).

A atuação do governo de fato na dinâmica espacial de Buenos Aires pode ser exemplificada através da análise das ações realizadas pelo intendente ou prefeito, o brigadier Cacciatore, indicado pelo governo nacional. Tais ações estavam contempladas dentro da estratégia adotada pelo poder municipal, que foi chamada por Oszlak (1991) de "ciudad blanca": "En el año 2000, nuestra ciudad será hermosa, sana y eficiente (...)", era o discurso dos ditadores (LACARRIEU, 2007, p.54). Com o objetivo de apresentar este modelo de cidade branca e limpa, uma declaração de 1980 feita pelo Diretor da Comisión Municipal de la Vivienda (CMV), Dr. Guillermo Del Cioppo, define claramente o interesse principal do plano e o público ao qual estava dirigido, ou a melhor cidade para as melhores pessoas: 
No puede vivir cualquiera en ella. Hay que hacer un esfuerzo efectivo para mejorar el hábitat, las condiciones de salubridad e higiene. Concretamente: vivir en Buenos Aires no es para cualquiera sino para el que la merezca, para el que acepte las pautas de una vida comunitaria agradable y eficiente. Debemos tener una ciudad mejor para la mejor gente. (COMPETENCIA, 1980, apud OSZLAK, 1991, p.78).

A condição das classes de menor renda, nesse momento, contrastava brutalmente com o embelezamento e modernização pelos quais passava a cidade, em decorrência da ausência de políticas de interesse social e em meio a uma crise política, econômica e institucional da Argentina.

Assim, tendo em conta o objetivo de "blanqueamiento de la ciudad" e as ações que compreendia, torna-se extremamente importante analisar seus efeitos na organização espacial, em especial, nos processos que interferiram e modelaram a cidade conforme os interesses políticos vigentes na época. A política de "limpeza" era parte de uma estratégia deliberada que se desenvolveu a partir da adoção de certos modos de operar sobre a cidade e da aplicação de novas normativas, que visavam como resultado a segregação sócio-espacial, na medida em que a população de menos recursos foi expulsa para fora dos limites da cidade, com o intuito de garantir a imagem de uma cidade moderna, desenvolvida e, principalmente, socialmente homogênea.

Porém, o período objeto deste estudo, a despeito de ter causado profundas transformações na cidade, não permitiu estabelecer grandes rupturas de ordem e tendências, e sim, mais precisamente, impôs a Buenos Aires "complejos procesos de mediación entre continuidad y cambio" (SILVESTRI \& GORELIK, 2000, p.463).

\section{O Plano de Erradicação de Favelas}

La Municipalidad, responsable de la urbanización y el ornato de la ciudad, no puede ni debe tolerar la proliferación de construcciones de emergencia, que por estar reñidas con elementales necesidades materiales y espirituales de la vida humana, son contrarias a la salud de la población. (Comunicado Oficial no Jornal Clarín, 26/8/76, apud OSZLAK, 1991, p.157).

As favelas, conhecidas como "villas de emergencia" na Argentina, surgiram no período do segundo pós-guerra, como alternativa de moradia provisória para aqueles estratos sociais que não tinham condições de ter acesso a uma casa própria. O acesso à moradia era uma providência fundamental para a permanência desta população nas cidades, um fenômeno que caracterizou as grandes metrópoles latino-americanas, provocado, fundamentalmente, pela migração de população do campo para a cidade atraída por uma ampla demanda de mão de obra, gerada pela industrialização e o crescimento do setor de comércio e serviços.

Embora as primeiras villas tenham surgido na década de 1930, o fenômeno passou a ter maior envergadura a partir da década seguinte, no marco de intensas migrações internas, direcionadas principalmente ao litoral do país. Durante longos períodos a população das favelas 
se reproduziu de forma significativa, uma vez que foram toleradas, pois representavam uma solução temporária para o problema habitacional, gerado por uma explosão demográfica não acompanhada do desenvolvimento urbano nas cidades. Como indicado por Gazzoli (2007), a partir da década de 1960, a Argentina passou por mudanças no sistema produtivo industrial, devido à crise das médias e pequenas empresas, que haviam perdido a competitividade graças ao ingresso de grandes capitais estrangeiros, que começaram a dominar as grandes empresas. Neste momento, se requeria maior capacitação da mão de obra no mercado de trabalho e, portanto, iniciou-se um período de exclusão de trabalhadores menos qualificados, fenômeno que se consolidou nos anos 1970 e se estendeu até a atualidade. Durante estes mesmos anos, a taxa de crescimento anual dos moradores de favelas atingiu 20\% (BELLARDI\&DE PAULA, 1986).

Ao mesmo tempo, foi um período político caracterizado por uma profunda instabilidade, com grande alternância entre governos militares e democráticos. A presença das favelas foi ganhando importância até se converter em um dos assuntos prioritários das agendas governamentais. Várias posturas foram adotadas em relação aos assentamentos irregulares e favelas em cada gestão, desde políticas que se baseavam no diálogo com os movimentos organizados de villeros até as mais radicais, do ponto de vista social. Desta forma é que, em 1956, se cria a Comisión Municipal de La Vivienda (CMV) e se elabora um plano de erradicação de favelas.

Durante o governo do Presidente Illia (1963-1966), em nível municipal, se sancionou em 1965 o Plano Piloto, que propunha a erradicação definitiva das favelas, porém previa também um plano de construção de habitações destinadas aos moradores destas, cujo acesso se daria através de um programa de financiamento.

Com o golpe militar em 1966 houve uma mudança importante em relação ao problema. Foi lançado o Plan de Erradicación de Villas de Emergencia de la Capital Federal y del Gran Buenos Aires (PEVE). Nessa época, a população favelada na região metropolitana atingia duzentos e oitenta mil pessoas. O plano objetivava dar solução habitacional aos quase setenta mil villeros da Capital e duzentos e dez mil do conurbano bonaerense. O PEVE foi considerado a proposta oficial mais ambiciosa até aquele momento, não somente pelos objetivos a que se propunha (em termos de números de habitações a construir e favelas a erradicar), mas também pela complexa estrutura administrativa criada para tal (BELLARDI \& DE PAULA, 1986). Estava prevista a construção de dezessete Núcleos Habitacionales Transitorios (NHT) para os moradores de favelas, que serviriam para a readaptação das pessoas desalojadas, com o intuito de "reeducá-los" para inserção na sociedade. O primeiro NHT só foi construído em 1969, porém, nenhuma habitação social definitiva foi concretizada e ainda hoje os NHTs existentes têm residentes permanentes morando em condições precárias (BLAUSTEIN, 2006). O Plano fracassou totalmente.

A chegada do General Lanusse ao poder, em 1971, alterou significativamente o enfoque deste assunto, abrindo um novo espaço de discussão para as reivindicações das populações 
faveladas. O Estado cedeu diante de várias demandas, visando obter o apoio dos setores populares, cujas ações no âmbito urbano e na esfera política começavam a ter um peso expressivo (BELLARDI \& DE PAULA, 1986). Nesse sentido, a criação do fundo FONAVI (Fondo Nacional de La Vivienda) evidenciava o grau de importância outorgada ao assunto da habitação dos moradores de favelas. O FONAVI foi criado pela lei 21.551, em 1972, na qual se determinava a destinação de uma porcentagem mínima de 30\% para financiar as políticas de erradicação, como proposta de resolução dos problemas dos assentamentos irregulares em Buenos Aires. Essa lei estabeleceu um fundo que se constituiria através da arrecadação de $2,5 \%$ das remunerações salariais e do imposto de $1,5 \%$ sobre as do setor pecuário, para um destino específico a ser controlado pelo governo nacional.

Sob o peronismo novamente, a partir de 1973, aprofundaram-se algumas das tendências do governo anterior, em relação à situação de precariedade nas favelas existentes. Segundo Yujnovsky (1984), os planos destinados a estes setores da população agora não apontavam como solução a "erradicação" e sim a "transformação". O instrumento utilizado foi o incremento do financiamento público, que destinou $20 \%$ dos seus fundos para as moradias individuais em lote próprio e o restante para a construção de conjuntos habitacionais. Foram descartadas completamente as soluções com moradias transitórias e em seu lugar se propôs a construção de grandes prédios de habitação social para onde seriam transferidos os moradores das favelas.

Quando os militares assumiram novamente o poder, em março de 1976, a cidade de Buenos Aires contava com uma população favelada de 224.885 pessoas, o que incluía nove mil moradores de NHTs, segundo relatório oficial. Nesse mesmo ano, o prefeito Cacciatore anunciava as medidas a seguir: finalizar as obras de conjuntos habitacionais já iniciadas no governo anterior - o que permitiria a erradicação de algumas favelas - e congelar o crescimento desses assentamentos para evitar o aprofundamento do problema. As políticas desse governo referentes ao assunto tiveram um foco diferente das anteriores, segundo Oszlak (1991:158):

(...) el problema de las villas no se reducía a una cuestión habitacional, sino que involucraba además aspectos estéticos ("ornato de la ciudad") y morales ("necesidades espirituales de la vida humana") que trascendían los intereses y carencias de los sectores directamente implicados, y afectaban al conjunto de la vida urbana (Grifo original).

Ainda segundo o autor, se tentou redefinir a questão villera como um problema que não se limitava à questão do déficit habitacional, mas representava uma ameaça à qualidade de vida da população da cidade, com o intuito de validar as ações de despejo perante a opinião pública. Criou-se um estigma do morador de favela para legitimar as políticas drásticas que foram realizadas no marco do Plan Integral de Erradicação, sancionado no ano 1977, através do qual se nomeou a CMV como "organismo idôneo" responsável pela concretização do plano. No entanto, a partir da análise da definição empregada pelo mesmo organismo para identificação 
das favelas, observa-se que a erradicação destas urbanizações era a única solução possível perante a "ameaça" que representavam para a qualidade de vida dos outros moradores da cidade de Buenos Aires. A CMV definia as favelas como:

Asentamientos ilegales de familias en tierras fiscales y en algunos casos de terceros particulares, con construcciones que no cumplen normas mínimas edilicias y de habitabilidad, sin infraestructura de servicios, ni salubridad e higiene compatible con la vida urbana, configurando un alto grado de hacinamiento poblacional y familiar (BELLARDI\&DE PAULA, 1986:23, grifo próprio).

Em primeiro lugar, se realizou um levantamento físico, identificando a partir de fotos aéreas as localizações e extensões das favelas, e um levantamento censitário, visando contabilizar e caracterizar a população favelada. Esta primeira fase culminaria com a entrega de um Certificado de Asentamiento Precario (CAP) a cada unidade levantada, fato que pressupunha que ninguém podia morar em favela sem autorização, que deveria ser apresentada para qualquer autoridade municipal, quando requerida. Posteriormente, se estabeleceram certas pautas fundamentais que estruturariam a atuação da CMV a partir de três ações: a primeira consistia no congelamento dos núcleos identificados, impedindo o surgimento de novas construções, ou a ampliação dos existentes. Numa segunda etapa, se procurou desestimular a permanência da população nas favelas, não se permitindo qualquer atividade além da residencial, ou seja, coibindo todo local de uso comercial ou industrial. A última etapa do programa efetivaria a erradicação definitiva das favelas, em que foram oferecidas possibilidades de "solução" habitacional aos moradores (BELLARDI\&DE PAULA, 1986): transferência a terreno próprio; retorno ao país ou província de origem; regresso por meios próprios; ajuda para obtenção de crédito; realocação em outros assentamentos. Estas opções contariam com a colaboração da CMV para facilitar o acesso aos traslados, ajudas financeiras, créditos ou subsídios necessários.

Finalmente, o sucesso do plano seria atingido a partir do Ordenamiento Social y Edilicio da Cidade de Buenos Aires, incorporando os terrenos liberados pela erradicação das favelas à trama legalizada do resto da Capital. Desta forma, a atuação durante este período da CMV resultou em uma série de ações dramáticas do ponto de vista social, porém algumas delas foram consideradas exitosas em relação ao propósito das políticas de branqueamento da cidade. Como resultado, foi elaborado um relatório oficial, detalhando as ações da CMV e seus efeitos, com uma abrangência de dados até junho de 1980, publicados no chamado Libro Azul.

Para se ter ideia da eficiência do processo, segundo os dados oficiais do Libro Azul da CMV, em 1976 contabilizavam-se quase 225 mil moradores em favelas na capital. Com a atuação da CMV, em 1977, a cifra chegava aos 146 mil moradores; no ano seguinte cairia para 115 mil, depois, no ano posterior seria de aproximadamente 52 mil, e finalmente, em 1980, ano de encerramento do relatório, a população favelada dentro da cidade era de 40.553 pessoas. 


\begin{tabular}{|c|c|c|c|}
\hline População & Total em favelas & Total da cidade & $\begin{array}{c}\text { \% população em } \\
\text { favela em relação ao } \\
\text { total }\end{array}$ \\
\hline 1962 & 42.462 & $2.966 .634(1960)$ & 1,43 \\
\hline 1976 & 224.885 & $2.972 .453(1970)$ & 7,57 \\
\hline 1978 & 115.236 & $2.972 .453(1970)$ & 3,88 \\
\hline 1979 & 51.845 & $2.972 .453(1970)$ & 1,74 \\
\hline 1980 & 40.533 & 2.922 .829 & 1,39 \\
\hline 1991 & 52.608 & 2.965 .403 & 1,77 \\
\hline 2001 & 107.422 & 2.776 .138 & 3,87 \\
\hline 2010 & 163.587 & 2.890 .151 & 5,66 \\
\hline
\end{tabular}

Tabela 1 - População favelada na Cidade de Buenos Aires entre 1962 e 2010.

Fonte: Elaboração própria a partir do quadro de OSZLAK (1991); CRAVINO, del RÍO, DUARTE (2008) e da publicação dos dados do Censo 2010 da Dirección Nacional de Estadísticas y Censos (Ministerio de Hacienda/GCBA) (2011).

Contudo, no final de 1979, ganharam força vozes opositoras à atuação do Estado, numa luta que reuniu vários setores da Igreja, inclusive a organização católica Cáritas, dependente do arcebispado, e os conhecidos como curas villeros que tinham uma atuação ativa junto aos movimentos organizados de moradores de favelas. Suas reivindicações tornaram-se públicas através de publicações em vários meios de comunicação, denunciando os métodos questionáveis levados adiante pelo poder público, gerando um conflito social que aumentava cada vez mais a partir da reorganização do movimento villero e que provocou um enfraquecimento da ação da CMV.

O Equipo Pastoral de Villas de Emergencia (EPV) estava constituído por um grupo de sacerdotes católicos, formado em 1969, a partir de uma iniciativa do Arzobispado de la Arquidiócesis de Buenos Aires, com o objetivo de atender aos moradores de favelas. Com o inicio das ações da CMV no marco do plano de erradicação, estes padres tiveram um papel importante na defesa dos interesses da população favelada. Conjuntamente com Cáritas, levaram adiante uma prática sistemática de denuncia das práticas e métodos aplicados durante as operações municipais dentro das favelas (BELLARDI \& DE PAULA, 1986). Na publicação da EPV intitulada "La verdad sobre la erradicación de las villas de emergencia en el ámbito de la Capital Federal", 
se constataram principalmente a prática violenta e mecanismos repressivos aplicados pelos funcionários municipais a partir de uma série de relatos testemunhais de moradores de favelas, assim como o descumprimento das ajudas creditícias prometidas pelo governo.

O efeito mais profundo dessas políticas de remoção e diminuição da população morando irregularmente dentro da cidade foi o destino dessas massas deslocadas. Segundo o relatório realizado pelos padres que moravam nessas comunidades, nenhuma das 'alternativas' de ajuda econômica através de créditos foram postas em andamento, nem qualquer tipo de assistência social.

A figura 1 mostra a localização das favelas removidas durante o período de 1969 a 1975 e o nível de erradicação de cada favela durante a última ditadura e sua distribuição na Capital. Percebe-se uma concentração muito maior de favelas na zona sul da cidade, assim como uma diferença estratégica na eleição das favelas a serem erradicadas nos diversos planos desde a década de 1960. Se por um lado observa-se que o alvo dos planos até 1976 eram aquelas localizadas, em sua maioria, no setor sul, por outro, constata-se que as primeiras favelas (e os casos mais exitosos nos termos do Plano de Erradicação) a sofrerem intervenção se localizavam nas áreas mais nobres. Contudo, também é valido salientar que muitas das favelas nos bairros ao sul se viram muito afetadas, atingindo percentagens de erradicação acima de $70 \%$.

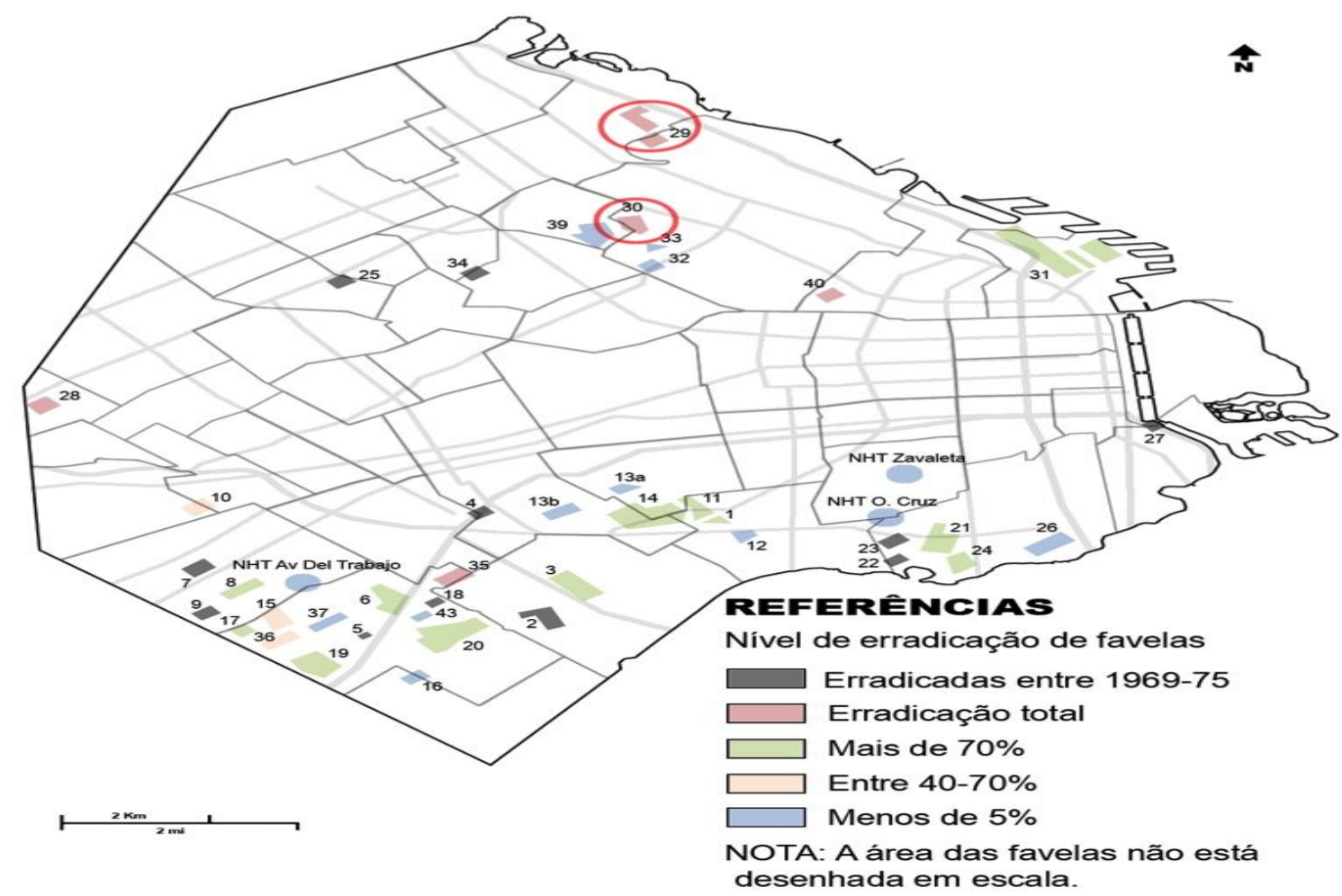

Figura 1 - Resultados dos Planos de Erradicação de Favelas dos períodos 1965-1975 e 1976-1980 na cidade de Buenos Aires. Em destaque os dois casos de estudo.

Fonte: Elaboração própria a partir do mapa de localização de favelas de DE LA TORRE (2008), Relatório sobre favelas erradicadas de 1980 da CMV (apud BELLARDI\&DE PAULA, 1986, p.20,21) e OSZLAK (1991, p.183). 
Após a implementação do Plano de Erradicação, se constatou um importante aumento da população estabelecida em assentamentos informais e um crescimento nas formas de apropriação fundiária irregular nos municípios mais afastados da cidade de Buenos Aires, aprofundando o desenvolvimento precário na área do conurbano bonaerense, que contava com recursos, serviços e infraestrutura muito inferiores aos da Capital Federal.

La ambición de la ciudad blanca, como Oscar Oszlak llamó hace más de una década a la política terrorista de "limpieza" de villas llevada adelante por Cacciatore fue precisamente una demostración dramática de esa "modernidad excluyente", de recorte de la ciudadanía usando al conurbano ya no como sector dinámico, como colchón de la metropolización, sino como basurero social (GORELIK, 1994, p.198).

Identificada, ainda na década de 1970, como uma cidade com alto padrão de sofisticação urbana, principalmente em função do "núcleo duro" portenho descrito por Lacarrieu (2007), a cidade de Buenos Aires caracteriza-se hoje como uma cidade repleta de problemas urbanos, com um mercado imobiliário que vem atuando intensamente na descaracterização de sua urbanidade. Paralelamente, em decorrência das crises sofridas pelo país no âmbito políticoeconômico e como consequência do modelo de país adotado na década de 1970, observa-se um crescimento importante de assentamentos informais na região metropolitana de Buenos Aires, simultaneamente ao aumento de empreendimentos de urbanizações privadas, muitas delas, enclaves auto-segregados direcionados a um público de alto poder aquisitivo.

Portanto, a combinação de fatores históricos que marcaram as intervenções urbanas em Buenos Aires, especialmente as ações ligadas às políticas habitacionais no último governo militar e os conceitos oriundos dos modelos de intervenção de renovação urbana, através da segregação sócio-espacial, formam a matriz principal para o entendimento sobre a evolução e os efeitos das políticas urbanas realizadas pelo Estado argentino no período da última ditadura.

\section{Estudo de caso: Bajo Belgrano e Colegiales}

A primeira fase do programa, prevista para ser realizada entre meados de 1977 e final de 1978 , determinava como prioridade a erradicação definitiva das favelas da zona norte da cidade, dentre as quais foram escolhidas, para estudo de caso, duas favelas entre as primeiras experiências de erradicação, a Bajo Belgrano (29) e a Colegiales (30) ${ }^{4}$, com o intuito de aprofundar o entendimento sobre os mecanismos e a atuação da CMV. Estas favelas constituíam exemplos de assentamentos privilegiados do ponto de vista de localização, com acesso a frentes de trabalho e proximidade de comércios, serviços e infraestrutura, características que faziam destes casos alvos prioritários de remoção, dado o interesse que havia pelos espaços

${ }^{4}$ Os números das favelas correspondem à numeração atribuída no levantamento de favelas da cidade nos relatórios do CMV e os nomes é como se conhecem mais popularmente, relacionados ao bairro onde estavam localizadas. Ao longo do texto se utilizaram as duas designações para se referir a estas favelas.

(c) Urbana: Rev. Eletrônica Cent. Interdiscip. Estud. Cid

Campinas (SP)

v.9, n.1 [15] p.224-250

ISSN 1982-0569 
remanescentes. Segundo Oszlak (1991), esta situação contrastaria dramaticamente com as condições de moradia, infraestrutura e serviços existentes nos lugares de destino da grande maioria dos habitantes erradicados.

\section{a. Bajo Belgrano}

A favela 29 se localizava na área conhecida como Bajo Belgrano e foi o primeiro caso de erradicação total no marco do Plan Integral de Erradicación realizado pelo último regime militar argentino.

A organização da Copa do Mundo de 1978, apenas dois anos depois da chegada do último governo militar ao poder, somada às políticas de limpeza e organização territorial para a cidade, resultou na escolha da Villa Bajo Belgrano como a primeira experiência de erradicação de favela a ser concretizada, por sua localização privilegiada na zona norte da cidade, a mais nobre, e a proximidade com o Estádio de River Plate, uma das sedes mais importantes dos jogos da Copa. No entanto, desde a década de 1940, a área de Bajo Belgrano tinha sido objeto de diferentes projetos urbanos, uma vez que, por sua posição estratégica perto do rio e sua localização dentro da cidade consolidada, despertou o interesse de diversas instituições estatais e municipais. Sua história foi marcante, principalmente durante os anos peronistas.

O Estudio del Plan de Buenos Aires (EPBA), criado em 1947, iniciou a elaboração de um plano para a cidade e das obras necessárias para a reestruturação da mesma. Sob o lema "La ciudad vuelve a asormarse a su río olvidado", Bajo Belgrano foi um dos alvos dos esforços projetuais do EPBA, alvo de um projeto de urbanização exemplar na transformação da cidade, sob os rígidos parâmetros do racionalismo moderno (figura 2). No entanto, este projeto urbano foi descartado e a área foi destinada a obras de caráter social e assistencial de maior importância (BALLENT, 2009). Nesse sentido, no marco dos programas sociais da Fundación Eva Perón, se construíram a Ciudad Infantil e Ciudad Estudiantil nos terrenos vizinhos aos correspondentes à favela, que se desenvolveria com maior vigor nas décadas seguintes. Faziam parte de uma série de lares, designados com nome de cidades (Infantil, Estudantil e Universitária). A partir do golpe de 1955, as "Ciudades" foram abandonadas e os moradores expulsos, e depois de terem recebido diversas destinações, à mercê dos poderes políticos de ocasião ${ }^{5}$, finalmente, foram ocupados pelo Instituto de Rehabilitación del Lisiado ${ }^{6}$.

5http://www.evitaperon.org . Acesso em: 01/12/2012.

${ }^{6}$ Atualmente, segundo dados da municipalidade, nas antigas instalações da Ciudad Infantil, se localiza o Hospital de Rehabilitación Psicofísica e a Escola de Discapacitados Motores; os prédios da Ciudad Estudiantil e suas instalações são utilizadas pelo Centro de Formación Profesional da Universidad Nacional General San Martín (UNSAM). 

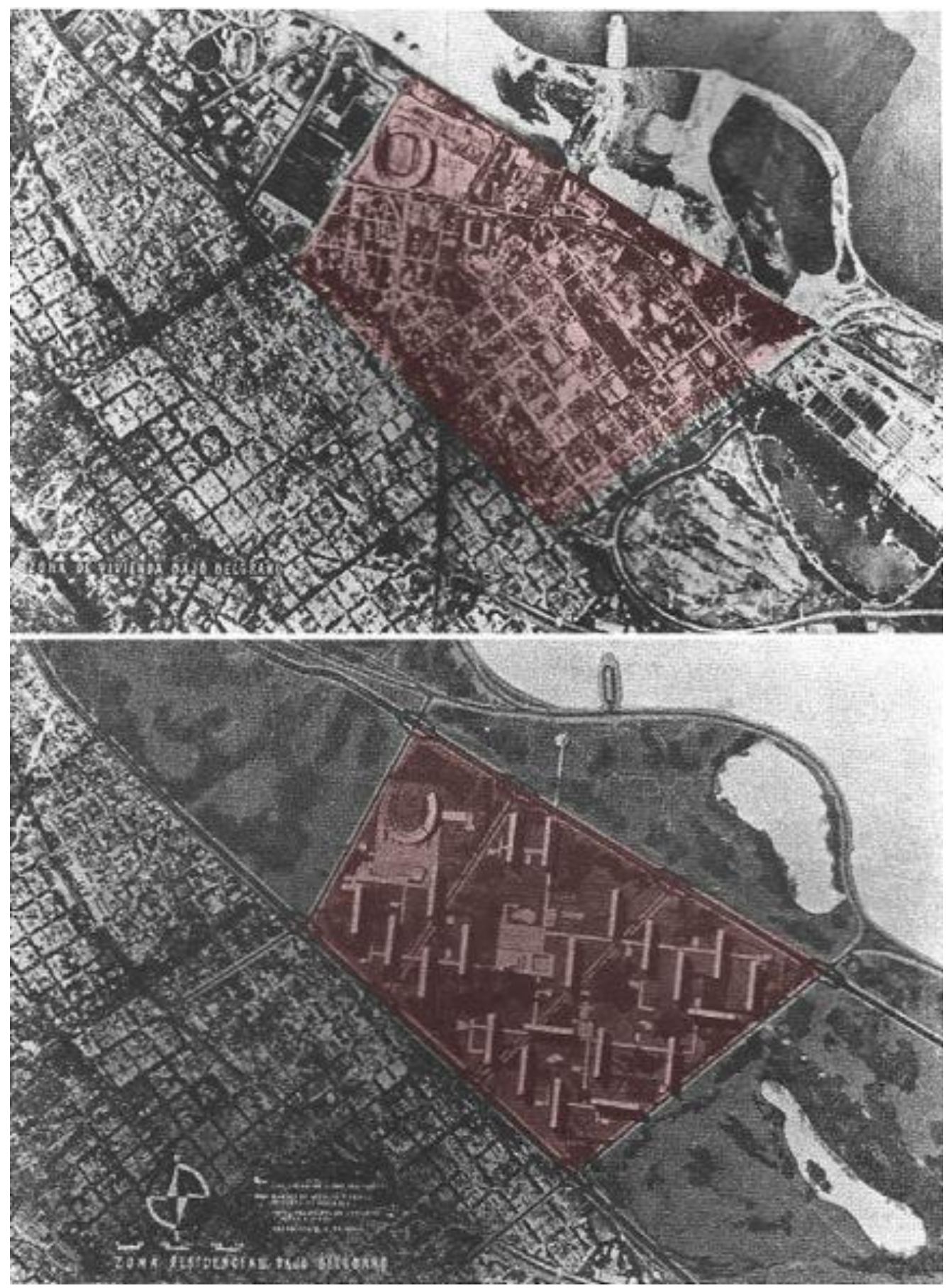

Figura 2 - Projeto para a urbanização do Bajo Belgrano, EPBA, 1949.

Fonte: BALLENT, 2009.

Em 1970, a CMV constrói o Conjunto Urbano La Pampa I, destinado realojar as pessoas erradicadas para as obras públicas de ampliação da Av. 9 de Julio. O projeto arquitetônico de caráter racionalista se diferenciava do tecido tradicional do bairro. Em 1980, e dois anos depois da erradicação da favela, a CMV completa, com duas torres, o quarteirão com o Conjunto Urbano La Pampa II, agora destinado aos funcionários municipais (DUNOWICZ, 2000). 


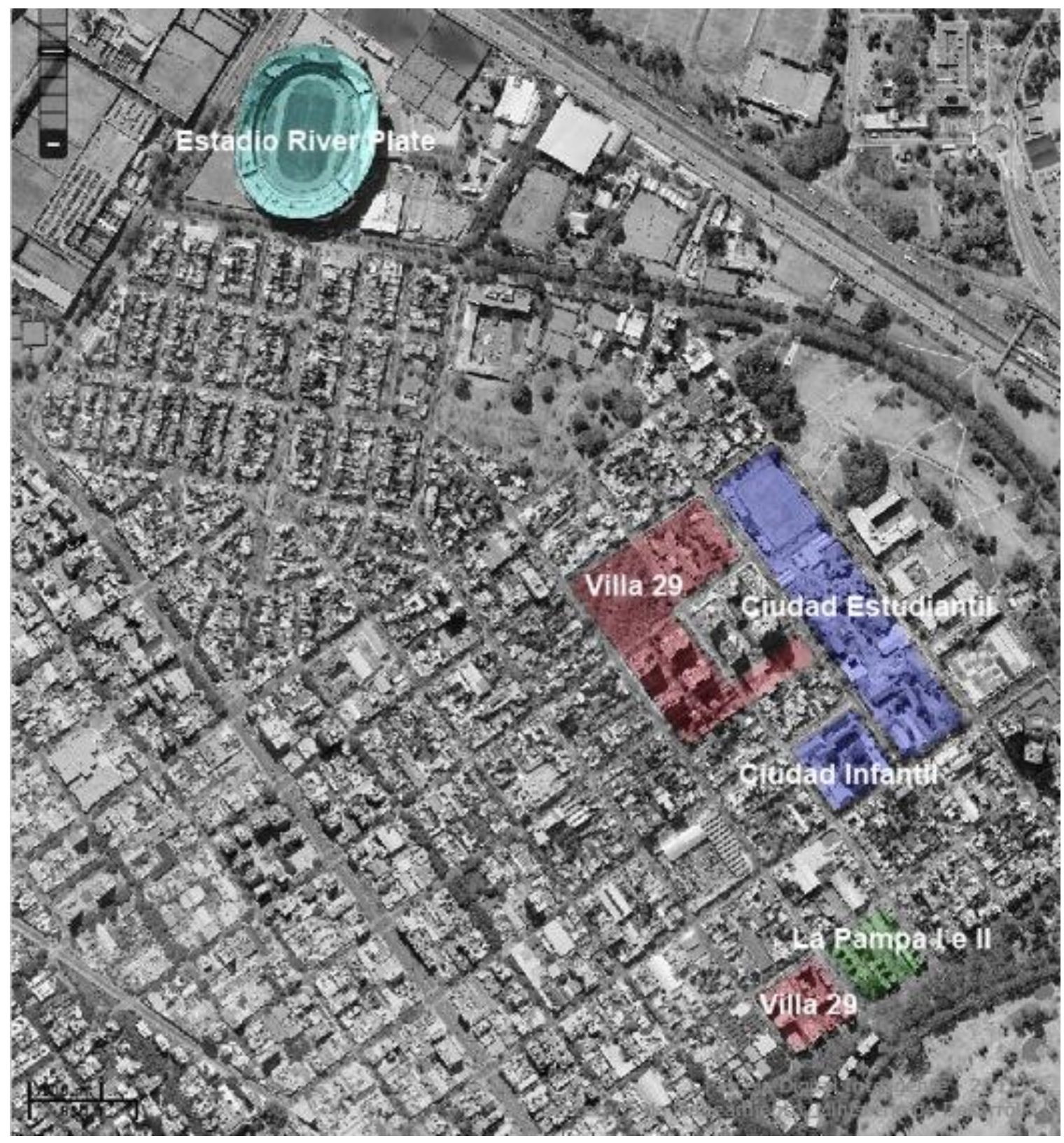

Figura 3 - Localização da Villa 29 em relação à Ciudad Infantil e a Estudiantil peronistas, os Conjuntos Urbanos La Pampa I e II e o Estádio River Plate, sede da Copa.

Fonte: Elaboração própria sobre imagem satelital atual.

A formação da favela remonta aos anos 1920, uma das mais antigas da cidade, quando algumas famílias de vendedores ambulantes e operários não qualificados construíram precárias moradias em um dos quarteirões vazios do bairro - que, por sua vez, foi lugar de queima de lixo - respeitando o traçado urbano de uma área predominantemente residencial. Ao final dos anos 1940, incrementou-se a população significativamente até ocupar mais de sete hectares, ocupando terrenos vazios em volta das obras de programas sociais peronistas. Na década de 1960, ganha maior extensão e as autoridades municipais constroem um muro perimetral para ocultar a favela (DE LA TORRE, 2008) (figura 4). 


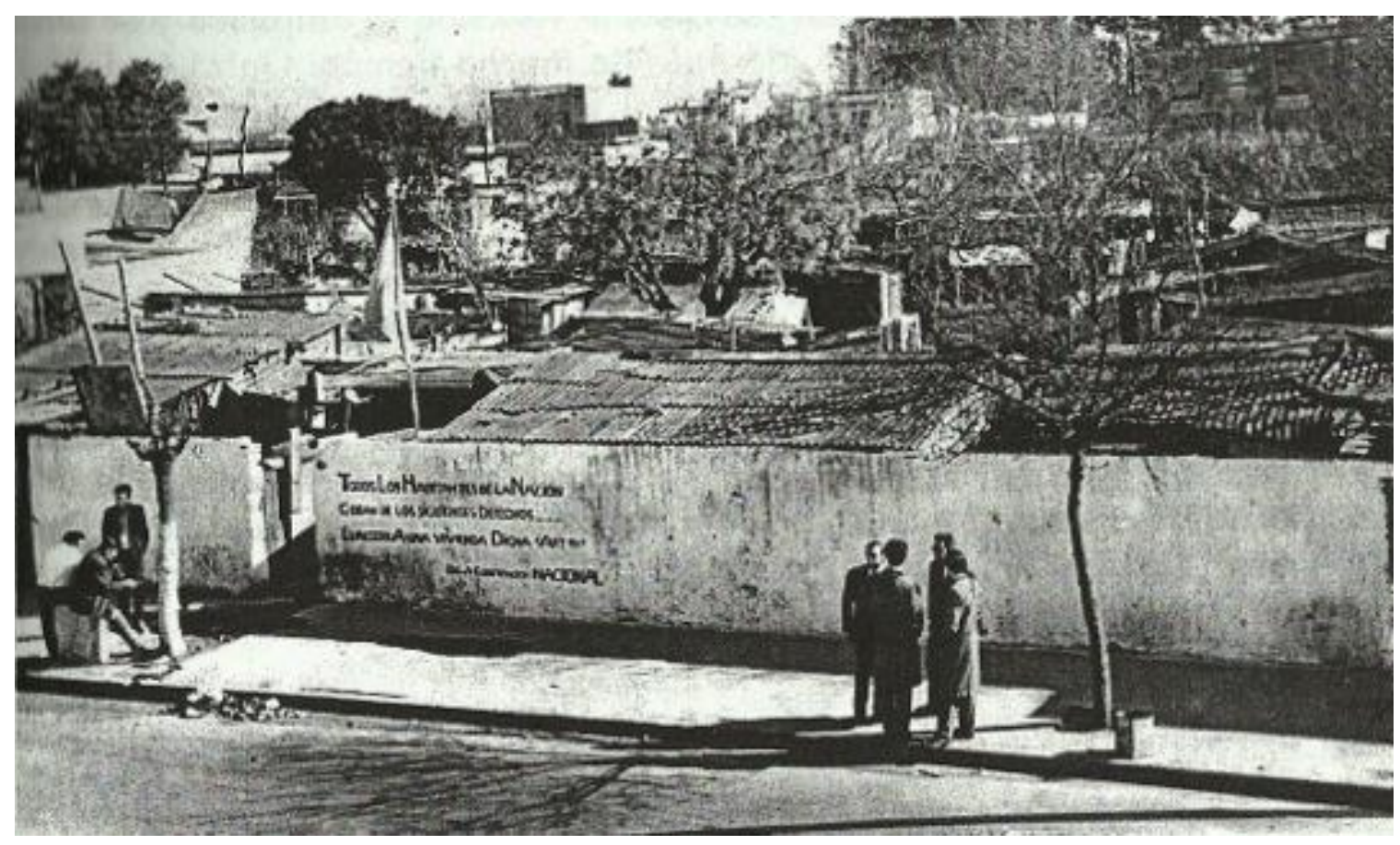

Figura 4. Villa Bajo Belgrano, 1965. Vista do muro perimetral. Fonte: YUJNOVSKY, apud ROMERO, 2000.

Já no período de interesse desta pesquisa, foi novamente o fator de localização de Bajo Belgrano o que despertou o interesse das autoridades municipais. Sua extensão, a proximidade ao Estádio sede da Copa de 1978 e a localização privilegiada na zona norte da cidade, converteram-na em alvo prioritário das ações de remoção do Plan Integral de Erradicação projetado para a cidade de Buenos Aires. Segundo Oszlak (1991), a intervenção individual em cada favela da cidade, submetidas à remoção uma de cada vez, facilitava a ação da CMV para efetivar o Plano e evitava uma resposta massiva, desmobilizando aos poucos as organizações dentro das favelas. Em março de 1978, num prazo recorde de sessenta dias, a CMV removeu a população e demoliu todas as construções que ocupavam os terrenos da favela, "recuperándose 7,2 hectáreas de tierras valiosísimas para un futuro ambicioso plan que llevará a um ordenamiento social y edilicio de la Capital Federal, como corresponde a toda 'Gran Ciudad' con envergadura cosmopolita" (BLAUSTEIN, 2006, p.77), conforme descrição de procedimentos do relatório oficial, no capítulo dedicado a esta favela. No dia 30 de julho desse mesmo ano, o jornal Clarín publicou declarações feitas pelo Diretor da CMV, Guillermo Del Cioppo, a respeito desta erradicação:

[Había que] devolver a la ciudad de Buenos Aires su mejor nivel (...) y que a partir de ese momento [la erradicación de la villa №29] el valor de los terrenos [había aumentado] cinco veces. (apud DE LA TORRE, 2008, p.63).

Analisando a imagem aérea de 1978, observa-se que o quarteirão isolado da favela, ao sul, já tinha sido completamente removido e haviam sido iniciadas as ações de limpeza dos 
terrenos liberados (figura 5). A área total liberada foi incorporada ao CPU de 1978 (figura 6) como Urbanização Determinada (U23), dividida em 10 zonas, das quais a zona 1, 2 e 5 correspondiam aos terrenos em questão (figura 7).
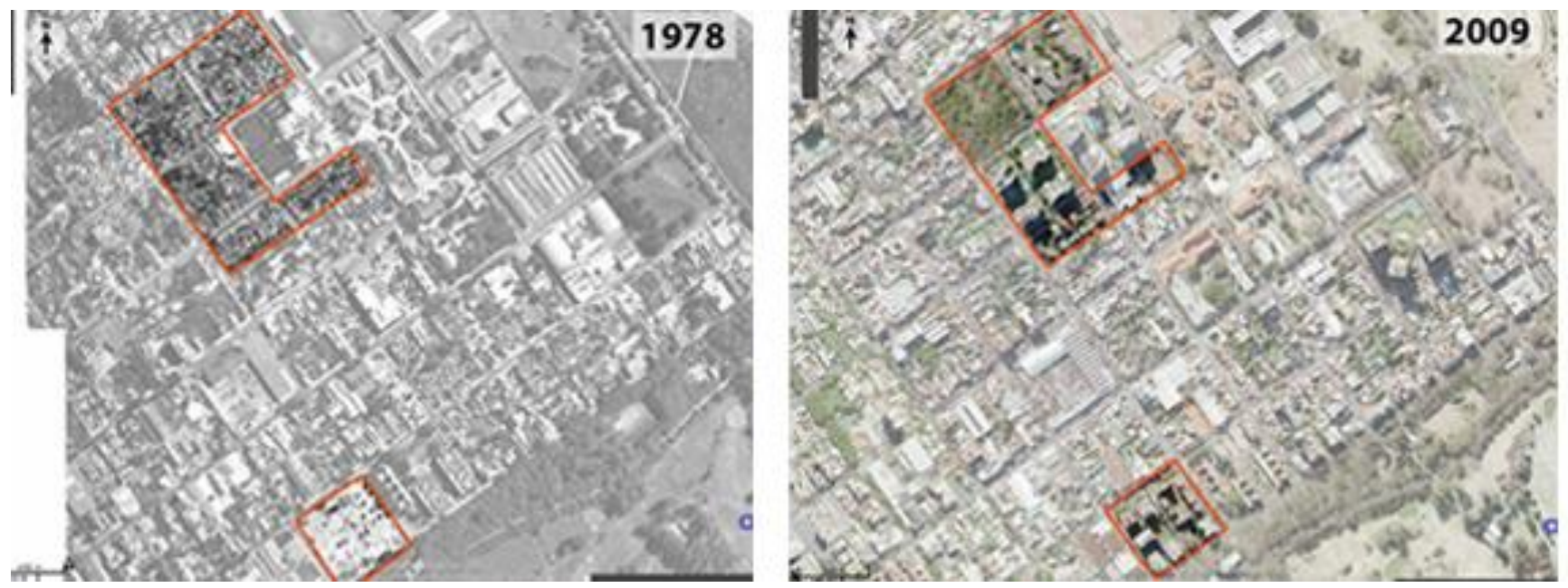

Figura 5 - Imagens aéreas de 1978 e de 2009. A esquerda se observa o primeiro quarteirão despejado; na imagem atual, se observam, nos terrenos antes ocupados pela favela, construções de torres contrastantes com a baixa densidade do resto do bairro.

Fonte: Elaboração própria sobre imagens aéreas de época (Disponível em: http://www.ssplan.buenosaires.gob.ar. Acesso: 28/11/2012).
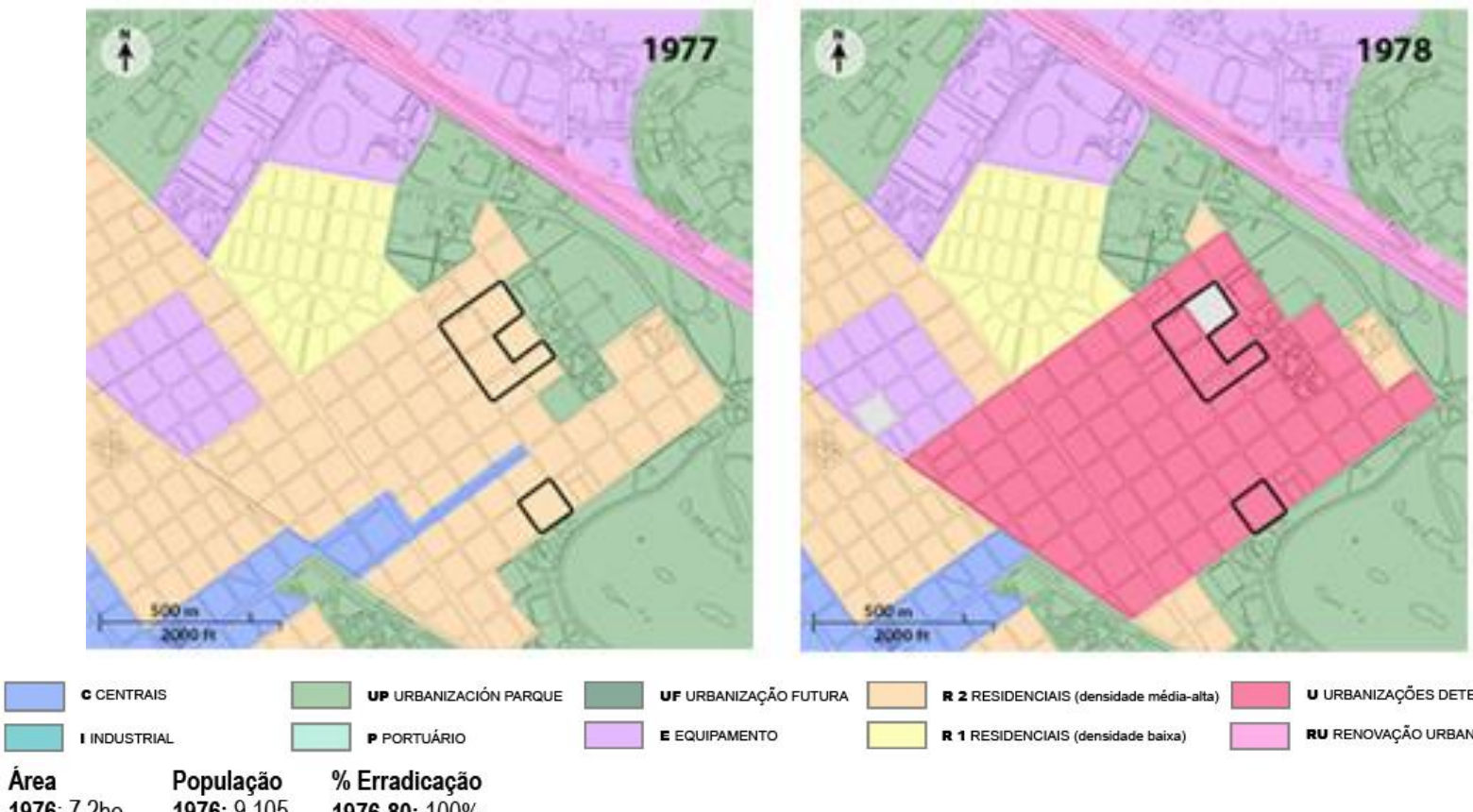

U URBANIZAÇöES DETERMINADAS RU RENOVAÇÃO URBANA

1976. 7 2he 1976:9.105 1976-80:100\%

1978: Ohe 1980: 0

Figura 6 - Mapas de zoneamento de 1977 e 1978; em destaque o perímetro da favela 29. Fonte: Elaboração própria sobre pranchetas de zoneamento dos CPUs. 


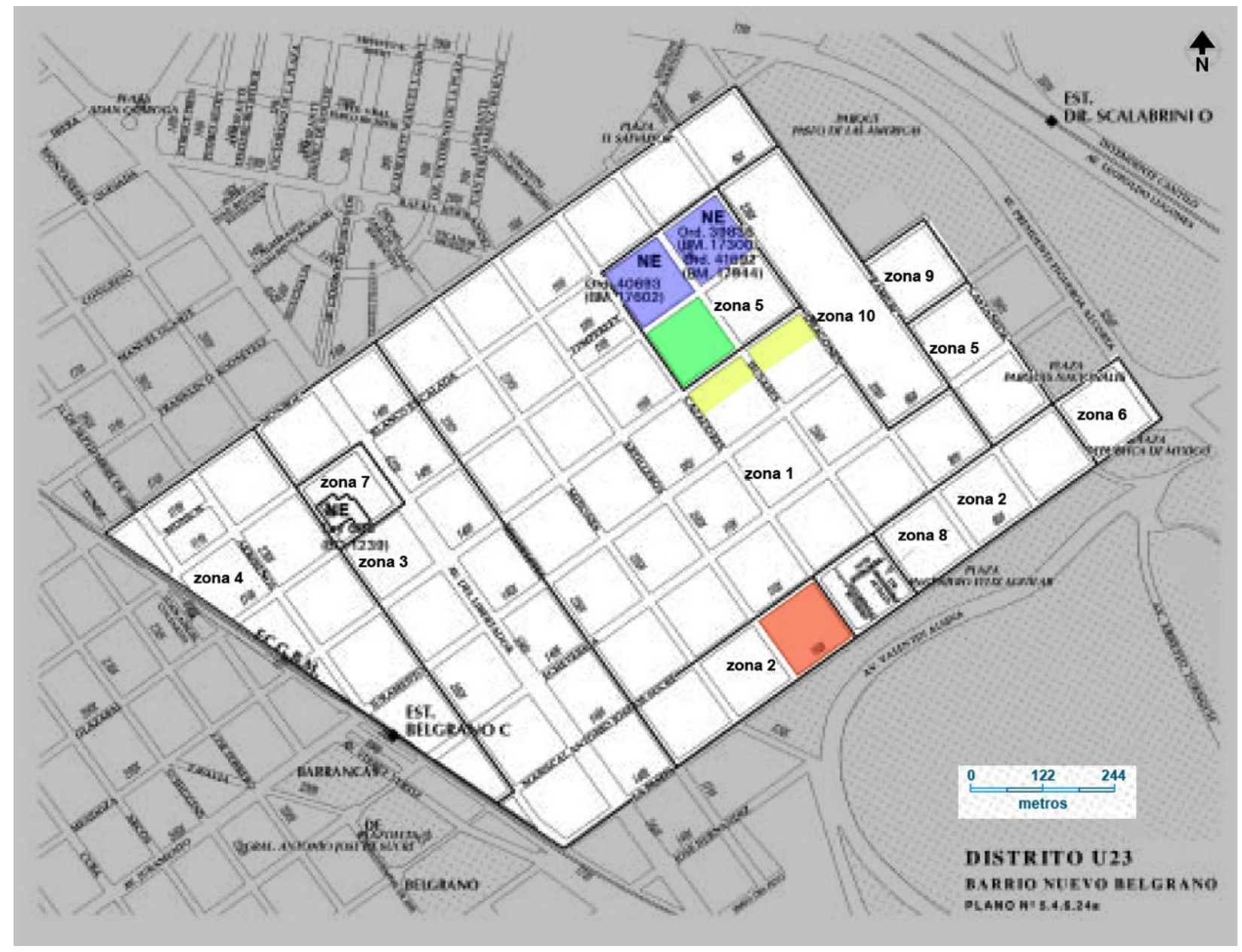

Figura 7 - Sobreposição de cores correspondente à área ocupada pela favela 29 sobre Mapa de Zoneamento do Distrito Urbanização Determinada U23: Barrio Nuevo Belgrano.

Fonte: Elaboração própria sobre CPU, 2006.

No setor da zona 1 (amarelo), realizou-se, num quarteirão, a divisão dos terrenos para construção de moradias unifamiliares, e no outro se construiu uma escola, seguindo os padrões arquitetônicos para tais instituições no período aqui tratado ${ }^{7}$. Dos quatro quarteirões da zona 5 (azul), dois deles foram submetidos a norma especial (NE), uma vez que os terrenos foram concedidos através de ordenamento municipal para a construção da embaixada russa ${ }^{8}$ e prédios para alojamento dos funcionários diplomáticos, estes últimos ainda sem construir ${ }^{9}$.

7Segundo Silvestre \& Gorelik, as intervenções no município: (...) Incluían la construcción de 60 escuelas (de las que se terminaron 24) continuando un plan propuesto por la Dirección Nacional de Arquitectura Educacional en 1969 y continuando, incluso, los presupuestos ideológicos típicos de la efervescente década anterior: coordinación modular, nuevas técnicas educacionales de tendencia piagetiana, y una imagen moderna pero sin estridencias, uniforme, basada especialmente en el uso del ladrillo y del hormigón visto" (IN: ROMERO, J. L. \& ROMERO, L. A., 2000, p.467).

${ }^{8} \mathrm{O}$ quarteirão recebeu a NE em 1978, mas não foi possível identificar se já desde então foi atribuída ao que depois seria a Federação Russa.

${ }^{9} \mathrm{~A}$ NE para este terreno foi outorgada no CPU de 1992. 
Nos outros dois quarteirões (verde), a zona 5 determina que a área estaria destinada à localização de habitação coletiva em edifícios verticais, admitindo-se unicamente edifícios de perímetro livre de maior altura. Por último, o quarteirão que se encontra na zona 2 (vermelho), ficou destinado à localização de habitação plurifamiliar de edifícios de apartamentos. As áreas liberadas foram destinadas para a construção de torres e prédios residenciais, alguns dos poucos exemplos de construções em altura que podem ser encontrados no entorno, onde predominam residências e ocupação de baixa densidade (figura 8 ).

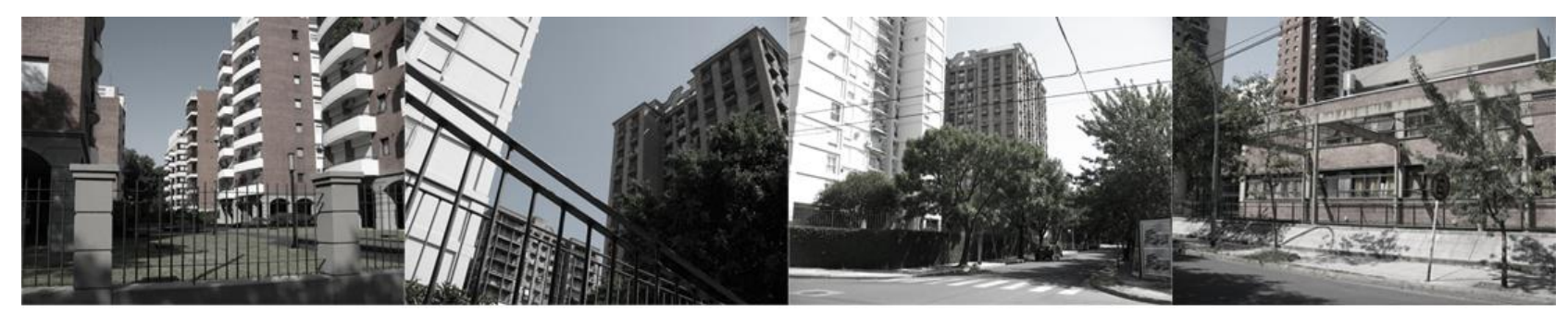

Figura 8 - Fotos atuais mostrando os novos empreendimentos realizados.

Fonte: Levantamento próprio, 2012.

Segundo dados do relatório da CMV (apud BELLARDI \& DE PAULA, 1986), o destino de $71,3 \%$ dos 2.021 moradores da favela 29 foi a mudança para um terreno próprio; 15,15\% foram transferidos a outra favelas ou NHTs; 9,21\% retirou-se por meios próprios; e o restante voltou à sua província ou país de origem.

A única mudança implementada na zona desde o começo da década de 1990, foi a delimitação dos terrenos correspondentes às Ciudades peronistas como distritos E, para conservação das instalações ali existentes.

Através da trajetória da favela Bajo Belgrano, é possível acompanhar as transformações sofridas pelo bairro. O percurso inclui desde a transformação de um bairro caracterizado pela baixa densidade, altos riscos de alagamento e pela localização de prédios assistenciais construídos durante o peronismo, até tornar-se um bairro muito valorizado atualmente, em termos econômicos, onde se construíram torres residenciais para alta renda, que convivem com construções mais baixas de outras épocas, reflexos de diferentes formas de atuação ao longo do tempo.

\section{b. Colegiales}

A remoção da favela 30 teve algumas características distintas em relação ao caso anterior que vale a pena salientar. Embora tenha sido também incluída na primeira etapa do Plan Integral de Erradicación, realizada com "sucesso", sua extensão era mais que o dobro da área ocupada pela favela Bajo Belgrano, com 30\% a mais de moradores.

$\mathrm{Na}$ sua origem, o entorno não era predominantemente residencial, como o da Bajo Belgrano, porém a favela Colegiales também se localizava na zona norte da cidade, em uma 
área próxima à linha ferroviária, onde existia uma bifurcação de vias que serviam de ingresso para uma estação de transferência, caracterizada pela presença de galpões e silos. Com a desativação da estação, os terrenos começaram a ser ocupados, por volta da década de 1950.

Analisando as imagens aéreas da época, em 1940 ainda se pode ver os terrenos vazios e a bifurcação das vias do trem atravessando o tecido do bairro. Já na imagem de 1965 observase o crescimento da favela nos terrenos desativados do sistema ferroviário, o começo da ocupação linear do desvio norte-sul das vias em desuso e, já instalada, uma Estação Elétrica da cidade. A imagem aérea de 1978, ano de conclusão da erradicação total da favela, mostra a extensão máxima desta urbanização informal, que chegou a ocupar, segundo dados oficiais da CMV, 17,5 hectares (figura 9).

Sua população estava constituída por $75 \%$ de origem argentina e o restante, $25 \%$, se dividia principalmente entre paraguaia e boliviana. Segundo o levantamento oficial, a favela contava com serviços de água corrente, luz elétrica, um centro sanitário e uma capela. Os trabalhos de erradicação definitiva foram iniciados em agosto de 1977 e se estenderam por mais de um ano (BELLARDI \& DE PAULA, 1986). Como no caso da favela 29, a maior parte dos moradores erradicados se transferiu para "terreno próprio", segundo o relatório oficial.

A análise da normativa urbana durante a década de 1970 dá conta destas mudanças. Em 1970, a área ainda era considerada Urbanização Futura (UF) assim como o resto dos espaços ocupados pelo sistema ferroviário; em 1977, com o primeiro CPU publicado, se transforma em área exclusiva de localização de equipamentos (E); por último, a partir de 1978, depois da conclusão da erradicação, e similar ao caso de estudo anterior, se considera como um distrito Urbanização Determinada (U20), de características particulares, que até hoje se mantêm, com algumas pequenas modificações (figura 10).
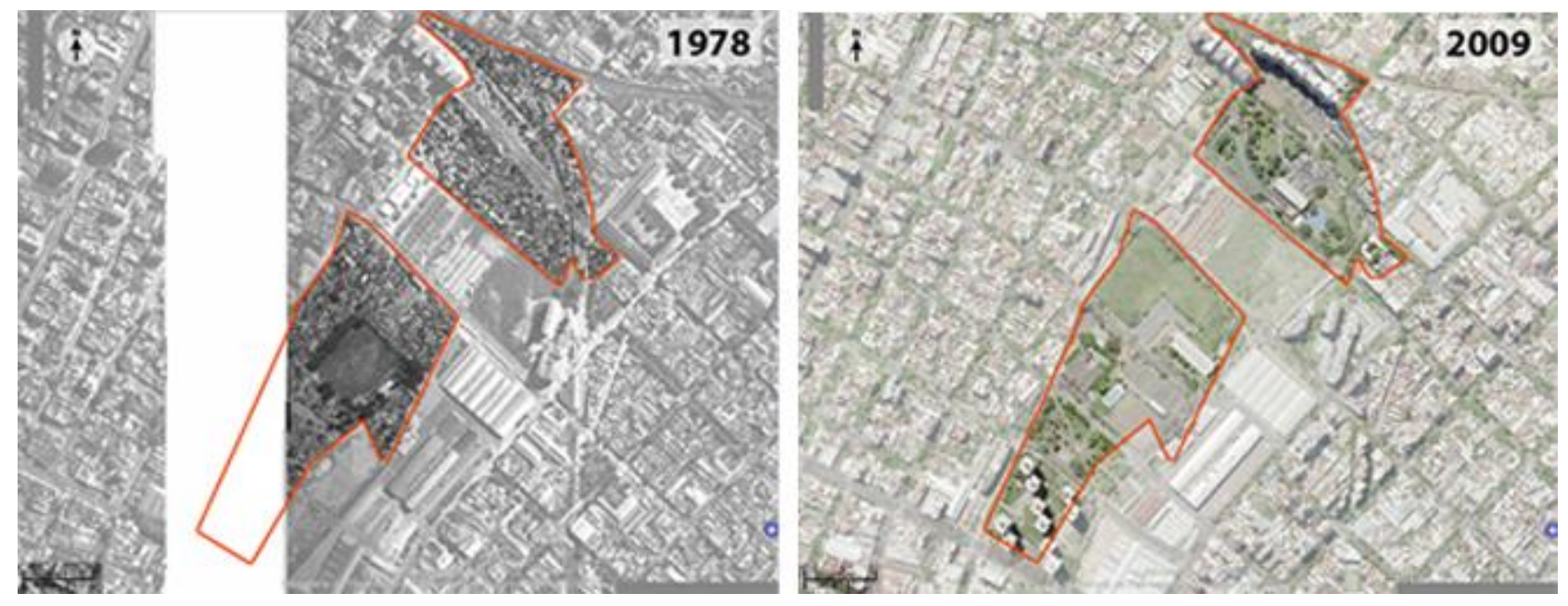

Figura 9 - Imagens aéreas de 1978 e de 2009. A esquerda se observa a favela 30 antes da erradicação na sua máxima extensão; a direita, na área desocupada foram se instalando uma variedade de equipamentos urbanos e educativos.

Fonte: Elaboração própria sobre imagens aéreas de época. Disponível em: http://www.ssplan.buenosaires.gob.ar. Acesso: 28/11/2012. 


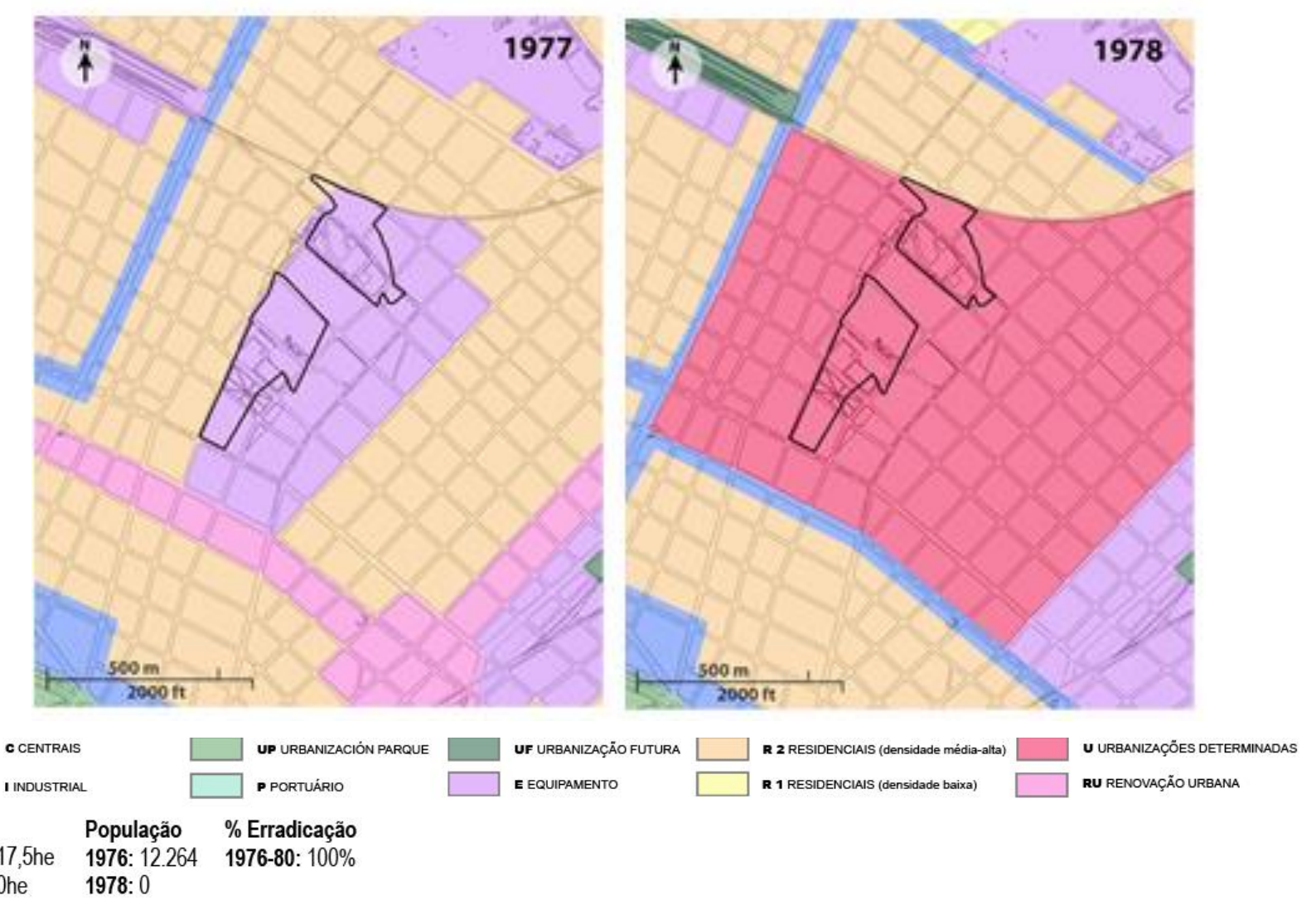

Figura 10 - Mapas de zoneamento de 1977 e 1978; em destaque o perímetro da favela 30. Fonte: Elaboração própria sobre pranchetas de zoneamento dos CPUs.

Com a completa erradicação da favela, os terrenos livres começaram a ser ocupados com equipamentos municipais (Estação de transferência do $\operatorname{CEAMSE}^{10}$, escolas) e privados (Pontificia Universidad Católica Argentina - UCA), assim como por conjuntos residenciais, sendo os primeiros dirigidos a uma classe média, e os mais recentes para a classe de mais alta renda. Já nas fotos atuais (figura 11) e na imagem aérea de 2009 (figura 12) e, observam-se os novos equipamentos mencionados, assim como a construção de prédios para classe média no quarteirão mais ao sul, facilmente identificados pela implantação fora do padrão do tecido tradicional, e a localização do campo da Facultad de Ciencias Agrárias da Pontificia Universidad Católica Argentina (UCA), com uma importante área verde ao seu redor, que hoje funciona como campo esportivo e de cultivo para a faculdade. Em 1988, começa a funcionar o Mercado de Pulgas, que continua suas atividades até hoje, só com uma breve interrupção entre 2005 e 2011 (site do Gobierno de la Ciudad de Buenos Aires) ${ }^{11}$.

${ }^{10}$ CEAMSE (Cinturón Ecológico del Área Metropolitana Sociedad del Estado), órgão criado em 1977, encarregado dos resíduos sólidos da cidade e da área metropolitana de Buenos Aires, formando uma área contínua que preenchia as zonas baixas com resíduos urbanos.

${ }^{11}$ http://www.buenosaires.gob.ar. Acesso em:04/12/2012. 


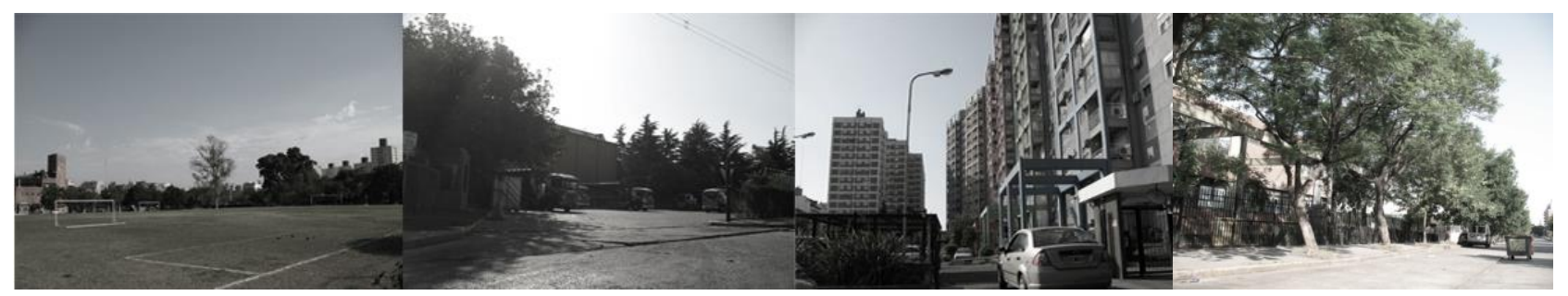

Figura 11 - Fotos atuais mostrando os novos empreendimentos realizados, de esquerda à direita: campus da UCA; Estação de transferência do CEAMSE; Conjunto residencial Torres de Colores; Escola municipal do mesmo plano (e padrão) de construção de escolas que a realizada nos terrenos da favela 29 no Bajo Belgrano.

Fonte: Levantamento próprio, 2012.

Finalmente, a história da Villa de Colegiales completa a cronologia desta área na década de 1990, quando sofreu transformações que tiveram um grande impacto no bairro até hoje. Por um lado, em 1992 a CMV constrói um conjunto de duas torres de interesse social, denominado Hogar I e II, com fundos de um financiamento compartilhado entre o FONAVI e uma cooperativa, cujos destinatários eram os associados à cooperativa (DUNOWICZ, 2000). Nos primeiros anos da mesma década, na área posterior da linha ferroviária, é construído o conjunto conhecido como Torres de Colores, composto por seis torres de grande altura diferenciadas pela cor da sua estrutura aparente, destinadas para a classe média.

Por outro lado, no ano seguinte, nos terrenos em frente ao conjunto de torres Hogar I e II, três dos escritórios mais conhecidos do país - MSGSSS, Dujovne-Hirsh e Juan Carlos Lopez e Asociados - se associaram para realizar um projeto de reciclagem dos velhos silos Minetti, transformando-os em lofts de alto padrão ${ }^{12}$. Este novo empreendimento se realiza num contexto de transformação da área Palermo-Colegiales, que passou a se caracterizar pela localização de lojas de design, gastronomia gourmet e empresas produtoras de televisão, área hoje conhecida como Palermo Hollywood.

Por último, a obras mais recentes do entorno se completam com a transformação do ex-Mercado Dorrego no Centro Metropolitano del Diseño (2003) e a inauguração da Plaza Mafalda (2005), parte do projeto Plazas Caracterizadas, ambas obras levadas a diante pelo Goberno de Cidade de Buenos Aires.

${ }^{12}$ Site do Escritório MSGSSS: http://www.msgsss.com.ar/. Acesso: 04/12/2012. 


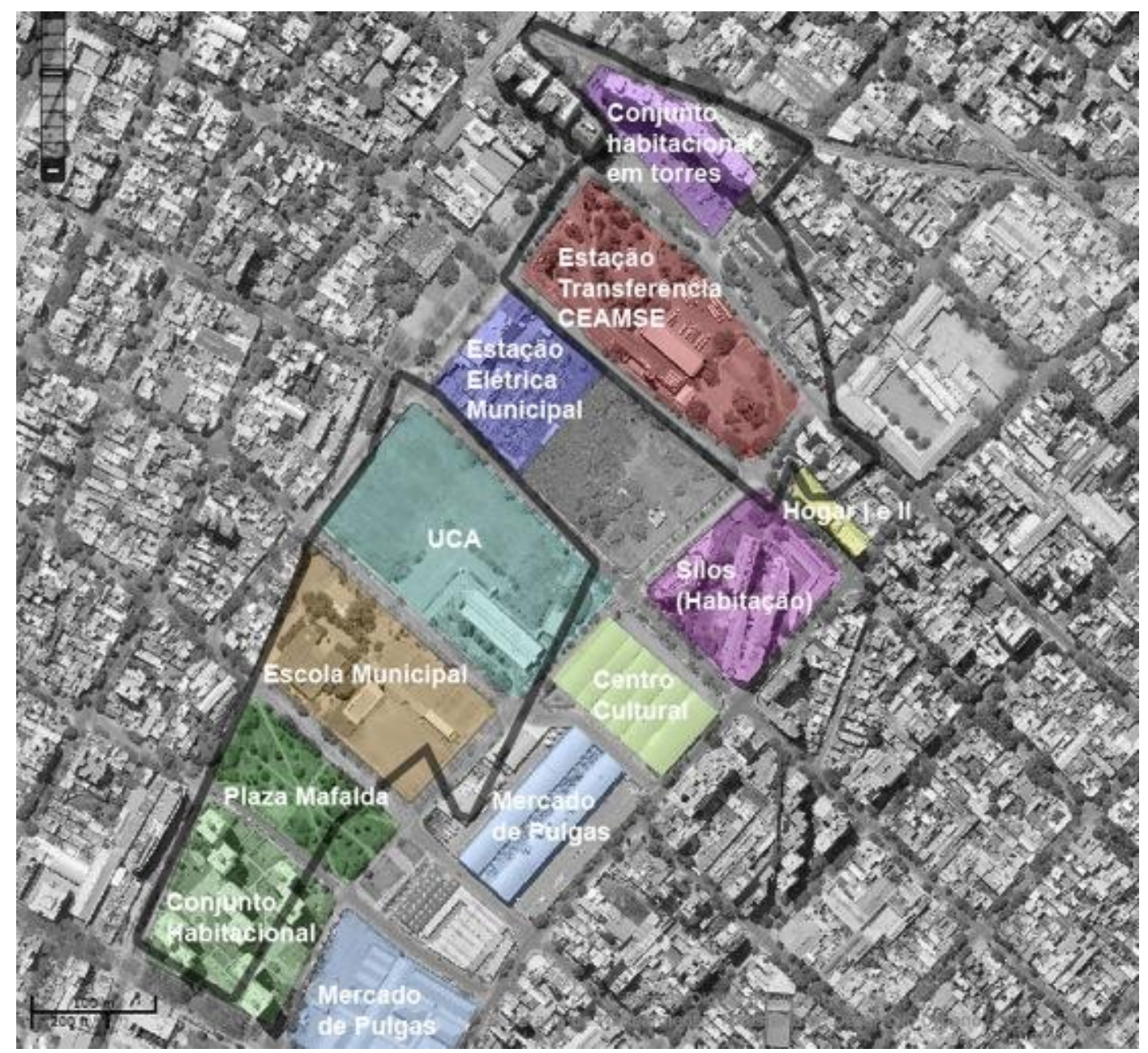

Figura 12. Equipamentos e construções atuais do bairro; em destaque o perímetro da favela 30. Fonte: Elaboração própria sobre imagem satelital (Google Earth, 2012).

\section{Considerações finais}

Entre as intervenções realizadas pelo Processo no âmbito municipal, o Plan de Erradicacion Integral foi uma das ações exemplares do governo militar. Mesmo que a solução de erradicação das favelas tenha se baseado em propostas já elaboradas anteriormente, o grau de efetividade atingido sob a gestão de Cacciatore foi único, assim como suas conseqüências para a cidade, revelando uma determinação do governo em recriar vazios num tecido urbano já muito consolidado, para ser possível operar os projetos modernizadores desejados.

A questão das favelas nas cidades foi mudando ao longo da sua história, refletindo-se nas diversas abordagens dos planos de cada momento. No caso do período aqui estudado, sob uma política estratégica de limpeza ou "blanqueamiento" de Buenos Aires e um contexto autoritário de ditadura, a questão das favelas teve uma abordagem muito contundente, porém podem-se destacar diferenças ao analisar cada caso.

Do ponto de vista mais geral, o plano facilitou particularmente a atuação dos diferentes agentes envolvidos no processo de produção da cidade, em especial, dos incorporadores 
imobiliários, configurando processos que visavam favorecer àquelas classes sociais "merecedoras" de uma cidade moderna como Buenos Aires. A pesar da política urbana ser homogeneizante e do Plan de Integral de Erradicação estar destinado a todas as favelas da cidade, percebe-se uma série de matizes nos diversos resultados e posteriores desdobramentos, que variam segundo cada caso, variação que está principalmente associada ao tamanho e à localização dentro da cidade. A partir do estudo dos casos escolhidos, pode-se perceber distintos resultados da implementação do plano, em especial, nas transformações e requalificações posteriores dessas áreas.

Nos exemplos das Villas Bajo Belgrano e Colegiales, inscritas na trama urbana mais consolidada e de menor porte, as áreas liberadas pela erradicação foram rapidamente requalificadas e incorporadas ao tecido tradicional e destinadas para habitação de setores de classe média e média-alta, ou para equipamentos variados. Porém, nem todas as favelas da cidade tiveram o mesmo desdobramento. No caso de algumas de maior tamanho ou localizadas em áreas com difícil acesso, e portanto, de menor interesse pelos incorporadores imobiliários, não foi possível obter o mesmo grau de requalificação preconizado pelo CMV, e muitas delas voltaram a se formar e crescer, mesmo após sofrerem também os efeitos das normas impostas pelo Plano.

Portanto, o Processo de Reorganización Nacional representou um período controverso na história argentina de vários pontos de vista. No campo das ideias e dos projetos de escala urbana, caracterizou uma etapa de materialização de várias questões que vinham sendo discutidas anteriormente, assim como preparou as bases para os acontecimentos que vieram nas décadas imediatamente posteriores. Pode-se dizer que foi um período onde se manteve o modo de pensar e operar de períodos anteriores, não só em nível local como na escala regional, porém incorporando reestruturações de ordem político-econômica que, por sua vez, estabeleceram as fundações de novas formas de pensamento e ação sobre o território, ainda que tenham apenas sido possíveis graças ao contexto particular de um governo autoritário.

A ideia de "merecimento" à cidade, em oposição ao resto da área metropolitana, foi o que diferenciou tais políticas em relação às das gestões anteriores, já que os planos consideravam a cidade como uma unidade isolada da sua área metropolitana, visão explicitada reiteradamente nas declarações oficiais. Estas políticas outorgariam à cidade o status de Capital de um país desenvolvido, através da modernização da sua estrutura, da homogeneização social de seus habitantes e do embelezamento das suas construções e espaços.

Aqui também foi possível evidenciar que o processo de construção de cidade deve ser entendido como um processo complexo atravessado por duas dimensões, uma de longa duração, que corresponde à continuidade de antigas ideias que vão se reformulando, e outra de curta duração, resultado de momentos de inflexão ou ruptura atrelados às decisões políticas pontuais de cada gestão. Por isso, sob o ponto de vista da análise do espaço urbano propriamente e com outro viés, este estudo se propôs analisar o vínculo indissolúvel entre a política e os modos 
operativos desenvolvidos, com o intuito de revelar alguns dos desdobramentos e suas "cicatrizes" no espaço urbano, frutos das intervenções realizadas aliadas às ações das diferentes entidades de governo. Por um lado, se observou certas continuidades nas políticas devido à permanência de conceitos técnicos que já vinham sendo operados antes e seguiram sendo aplicados depois deste período, e por outro, procurou-se assinalar particularidades dentro dessas políticas urbanas, realizadas num contexto de ditadura. Assim, uma observação mais detalhada das intervenções realizadas permite apontar uma multiplicidade de atores e fatores que operaram na produção da cidade, determinando as particularidades de cada caso e diferindo nos resultados da aplicação das políticas em um momento posterior.

Finalmente, se procurou colocar em evidência a complexidade por trás do processo de construção da cidade assim como sobre as esferas "técnica/política", uma vez que, embora os planos elaborados num determinado período sejam produtos de certas intervenções ou tomada de decisões conjunturais, também contemplam elementos dos ideários técnicos precedentes e é importante distingui-las enquanto instâncias atuantes na transformação do espaço.

\section{Referências}

BALLENT, A. Las huellas de la política: vivienda, ciudad, peronismo en Buenos Aires, 1943-1955. Bernal: Universidad Nacional de Quilmes: Prometeo 3010, 2009.

BELLARDI, M. \& DE PAULA, A. Villas Miseria: origen, erradicación y respuestas populares. Buenos Aires: Centro Editor de América Latina, 1986.

BLAUSTEIN, E. \& ZUBIETA, M. Decíamos ayer: la prensa argentina bajo el proceso. Buenos Aires: Colihue, 1998.

BLAUSTEIN, E. Prohibido vivir aquí. Una historia de los planes de erradicación de villas de la última dictadura. Buenos Aires: Punto de encuentro, 2006.

CORRÊA, R. L. O Espaço Urbano. São Paulo: Ática, Série Princípios, 4ª edição, 2005.

DE LA TORRE, L. Buenos Aires: Del conventillo a la villa miseria (1869-1989). Buenos Aires: Educa, 2008.

DUNOWICZ, R. 90 años de vivienda social en la Ciudad de Buenos Aires. Programa de Mantenimiento Habitacional, Centro de Estudios del Hábitat y la Vivienda, Secretaria de Investigación de Ciencia y Técnica, Facultad de Arquitectura, Diseño y Urbanismo, Universidad de Buenos Aires, 2000. 
GAZZOLI, R. Vivienda Social: Investigaciones, ensayos y entrevistas. Buenos Aires: Nobuko, 2007.

LACARRIEU, M. La 'insoportable levedad' de lo urbano. Revista Eure. Revista Latinoamericna de Estudios Urbanos Regionales, Santiago de Chile: v. XXXIII, n. 99, pp. 47-64,ago 2007. Disponível em:http://www.scielo.cl/scielo.php?pid=S0250-

71612007000200005\&script=sci_arttext

LIERNUR, J. F. Arquitectura en la Argentina del siglo XX: la construcción de la modernidad. Buenos Aires: Fondo Nacional de las Artes, 2008.

NOVICK, A. Los proyectos territoriales en perspectiva. In. CHARRIERE, M. [et al]. Planes, proyectos e ideas para el AMBA. Buenos Aires: CPAU, 2011, pp. 35-47.

OSZLAK, O. Merecer la ciudad: los pobres y el derecho al espacio urbano. Buenos Aires: Humanitas-CEDES, 1991.

SILVESTRI, G. \& GORELIK, A. Ciudad y cultura urbana, 1976-1999: elfin de laexpansión. In.ROMERO, J. L. \& ROMERO, L. A. (Orgs). Buenos Aires: historia de cuatro siglos. Buenos Aires: Grupo Editor Altamira, 2000, Tomo 2.

SOUZA, M. L. O Desafio Metropolitano: Um Estudo sobre a Problemática Sócio-espacial nas Metrópoles Brasileiras. Rio de Janeiro: Bertrand Brasil, 2000.

TORRES, H. El mapa social de Buenos Aires (1940-1990). Buenos Aires: Dirección de Investigaciones-Secretaría de Investigación y Posgrado, FADU, UBA, 1993.

YUJNOVSKY, O. Claves políticas del problema habitacional argentino. Buenos Aires: Grupo Editor Latinoamericano, 1984.

(c) Urbana: Rev. Eletrônica Cent. Interdiscip. Estud. Cid Campinas (SP) v.9, n.1 [15] p.224-250 